\title{
O Epílogo de 0 guarani e os caminhos do romance de Alencar
}

\section{Ricardo Souza de Carvalho}

Resumo: Este artigo apresenta uma leitura do Epílogo de O guarani como uma representação ficcional de um projeto para o romance alencariano, ao considerá-lo uma retomada do idílio Paulo e Virgínia de Bernardin de Saint-Pierre. Palavras-chave: José de Alencar, O guarani, romance brasileiro no século xıx, Paulo e Virgínia, Bernardin de Saint-Pierre.

Abstract: This article interprets the $\mathrm{O}$ guarani's Epilogue as a fictional project to José de Alencar's novel, based on Bernardin de Saint-Pierre's Paul et Virginie. Keywords: José de Alencar, O guarani, $19^{\text {th }}$ Brazilian novel, Paulo e Virgínia, Bernardin de Saint-Pierre. 
Entre 1872 e 1873, José de Alencar, diante de uma carreira consolidada de romancista, escreveu dois textos que procuravam justificá-la: o prefácio "Bênção paterna" ao romance Sonhos d'ouro, datado de 23 de julho de 1872, e a autobiografia literária Como e por que sou romancista, datada de maio de 1873, mas de publicação póstuma, em 1893. Esses dois escritos passaram a acompanhar a fortuna crítica alencariana a fim de nortear a compreensão de uma trajetória de vinte e um romances de temáticas, espaços e épocas diversos. Por outro lado, devem-se retomar as motivações de sua produção, pois se trata de um momento de contestação da autoridade literária de Alencar. No periódico Questões do Dia, de 1871 a 1872, Franklin Távora e José Feliciano de Castilho lançaram críticas demolidoras aos romances O gaúcho e Iracema - as Cartas a Cincinato, em consonância com novas tendências literárias e de pensamento contrárias ao romantismo que começavam a circular entre a chamada geração de 1870. Dessa maneira, "Bênção paterna" e Como e por que sou romancista podem ser lidos como respostas às Cartas a Cincinato, além de construírem uma coerência e uma explicação do conjunto da obra que não necessariamente presidiram o início da ficção de Alencar. ${ }^{1}$

Do longo prefácio do romance de 1872, logo se ressaltou o trecho em que Alencar descreve as três fases da literatura nacional em função de suas obras publicadas como uma verdadeira profissão de fé do romancista, como seu projeto de representar um vasto painel do Brasil. ${ }^{2}$ Voltando às três fases, percebe-se que a ordenação histórica não acompanha a sequência das edições. Assim, a fase "primitiva" ou "aborígine"

Antonio Candido, pelo menos em relação a "Bênção paterna", aponta que seja "possível que tais ataques hajam movido Alencar a refletir sobre o sentido da própria obra e tentar uma espécie de teoria justificativa, que não restringisse o seu valor nacional aos livros indianistas" (Formação da literatura brasileira. Momentos decisivos, v. 2 (1836-1880). 7. ed. Belo Horizonte, Rio de Janeiro: Itatiaia, 1993, p. 325). Já Valéria de Marco é mais incisiva: "A resposta às agressões de Semprônio e Cincinato viria em julho de 1872 neste texto que serve de prefácio a Sonhos d'ouro. É um revide irônico e altivo que apresenta uma reflexão orgânica e ampla para fazer calar a crítica apaixonada e assistemática das polêmicas cartas de Questões do dia" ( $O$ império da cortesã: Lucíola, um perfil de Alencar. São Paulo: Martins Fontes, 1986, p. 47).

2 Antes de encerrar a Formação da literatura brasileira, comentando brevemente o texto de Machado de Assis, "Instinto de nacionalidade", de 1873, Antonio Candido estende o papel de "Bênção paterna" à maturação do próprio processo que vinha estudando: "A essa altura, vencida a etapa do radicalismo nativista, o romantismo exprime afinal claramente, pela pena do seu escritor mais ilustre, o verdadeiro sentido da sua tarefa, que felizmente nunca traíra, mesmo quando a praticara sem consciência nítida. A literatura nacional aparece, então, como expressão da dialética secular que sintetiza em formas originais e adequadas a posição do espírito europeu em face da realidade americana: não como a ilusão estática de um primitivismo artificialmente prolongado" (CANDIDO, Antonio. Formação da literatura brasileira, op. cit., p. 326).

526 CARVALHO, Ricardo Souza de. O Epílogo de O guarani e os caminhos do romance 
conta com Iracema (1865); o período "histórico", o do "consórcio do povo invasor com a terra americana", é representado por O guarani (1857); e a terceira fase, a do país independente ainda em formação, inclui tanto o recente $O$ tronco do ipê (1871), quanto Diva (1864). Além disso, em tal fase contemporânea opera um contraste não apenas espacial, mas sobretudo cultural: de um lado, os romances “onde não se propaga com rapidez a luz da civilização, que de repente cambia a cor local, encontra-se ainda em sua pureza original, sem mescla, esse viver singelo de nossos pais, tradições, costumes e linguagem, com um sainete todo brasileiro"; e de outro lado, os romances da "luta entre o espírito conterrâneo e a invasão estrangeira", ${ }^{3}$ respectivamente, 0 que a historiografia literária cunharia como romance regionalista e romance urbano. Tanto a cronologia histórica, quanto a delimitação espacial explicitadas por Alencar nesse prefácio apenas esclareceram ao seu público - e mais ainda aos seus detratores - um sentido não facilmente percebido em obras tão diferentes entre si, mas o que não implicava uma nova organização a partir de então, pois ainda se sucederam quase simultâneos, em 1874, a fase "primitiva" com Ubirajara e, em 1875, o "sainete todo brasileiro" com $O$ sertanejo e a "importação contínua de ideias e costumes estranhos" com Senhora. De todos os modos, um grande projeto já fora delineado, cabendo ao leitor ou ao crítico identificar o lugar deste ou daquele romance.

Quanto a Como e por que sou romancista, deixa-se a temática para passar à filiação literária ao se valorizarem os romancistas europeus lidos por Alencar desde a adolescência e que lhe serviram como estímulo e modelo. Entre a variedade de autores, principalmente franceses, vislumbram-se duas linhas de força: o "poema da vida real", tendo como mestre Balzac e seu imenso panorama na Comédia humana, e o romance histórico e de aventuras, a partir de Alexandre Dumas, Walter Scott e James Fenimore Cooper. ${ }^{4}$ A convivência e a oscilação entre esses dois tipos de romance vigoraram durante a carreira de Alencar, bastando lembrar que em 1862, ao mesmo tempo em que publicava Lucíola, lançava os dois primeiros volumes de As minas de prata.

Diante do projeto ficcional mais ambicioso em termos da extensão e da variedade de sua matéria representada no século xıx brasileiro, a crítica ora tentou explicar uma suposta unidade, ora os motivos de uma inevitável diversidade. Antonio Candido se valeu da comparação com o exemplo francês para entender que a "saída" pelo tempo e pelo espaço teria compensado as acanhadas sugestões do meio urbano do Rio de Janeiro: 
$\mathrm{Na}$ sociedade francesa, a diferenciação sendo mais acentuada requeria maior especialização no tratamento literário e quase sugeria ao escritor a divisão em assuntos como núcleos de cada romance: vida política, alto comércio, comércio miúdo, bolsa, burocracia, clero, especulação imobiliária, prostituição, vida militar, lavoura, mineração, ferrovias, alcoolismo etc. Nos países pouco desenvolvidos, como o Brasil, esta especialização equivaleria talvez a uma diluição, e Alencar, tencionando seguir o levantamento de Balzac, resolveu o problema pela variação no tempo e no espaço geográfico, não na complexidade do social. O nosso regionalismo nasceu em parte como fruto da dificuldade de desdobrar a sociedade urbana em temário variado para o romancista. ${ }^{5}$

Alfredo Bosi, por sua vez, propõe que "conviria buscar o motivo unitário que rege a sua estrutura, e que, talvez, se possa enunciar como um anseio profundo de evasão no tempo e no espaço animado por um egotismo radical. Traços ambos visceralmente românticos". ${ }^{6}$ E o romance urbano entraria como uma contraposição a essa evasão - já assinalada pelo próprio Alencar em "Bênção paterna" - ao criticar a sociedade que cultua o dinheiro:

Na verdade, era uma crítica emocional que só oferecia uma alternativa: o retorno ao índio, ao bandeirante, e a fuga para as solidões da floresta e do pampa. O romantismo de Alencar é, no fundo, ressentido e regressivo como o de seus amados e imitados avatares, o Visconde François-René de Chateaubriand e Sir Walter Scott. O que lhe dá um sentido na história da nossa cultura e ajuda a explicar muitas das suas opções estéticas.7

Tanto em função do meio literário brasileiro, quanto do próprio escritor, essas formulações corroboram um amplo espectro de referências literárias, sinalizando daí uma possível razão para sua diversidade de romances. Um Alencar que queria ser ao mesmo tempo Scott e Balzac é quem encontramos em um momento crucial para a formação não só de seu romance, mas também do próprio gênero no Brasil, entre 1856 e 1857, ao travar a polêmica em torno ao poema épico $A$ confederação dos Tamoios, de Gonçalves de Magalhães, e ao lançar em folhetins o romance O guarani. Embora não haja nenhuma menção à polêmica de 1856 em Como e por que sou

CANDIDO, Antonio. De cortiço a cortiço. In: O discurso e a cidade. 3. ed. Rio de Janeiro: Ouro sobre Azul, 2004, p. 107. BOSI, Alfredo. História concisa da literatura brasileira. 33. ed. São Paulo: Cultrix, 1994, p. 137.

7 Idem, p. 137. 
romancista, a crítica tem ressaltado a relevância do episódio para a passagem do cronista dos jornais ao romancista. ${ }^{8}$ Se levarmos em conta, desde cedo, a ávida leitura e os projetos malogrados, o Alencar romancista demorou a estrear. Contudo, nas nove cartas publicadas entre 10 de junho e 15 de agosto de 1856 no Diário do Rio de Janeiro, o ataque cerrado contra uma malograda epopeia nacional tão aguardada - inclusive pelo imperador d. Pedro II - apontava que a matéria indígena e a colonização portuguesa exigiam um gênero que entre nós ainda se deleitava com os amores dos moços do Rio de Janeiro de Macedo; para a mudança, o Sr. Ig propunha um dos seus ídolos literários: "Estou bem persuadido que se Walter Scottt traduzisse esses versos portugueses no seu estilo elegante e correto; se fizesse desse poema um romance, dar-lhe-ia um encanto e um interesse que obrigariam o leitor que folheasse as primeiras páginas do livro a lê-lo com prazer e curiosidade". ${ }^{9}$

Em meio a outras referências evocadas nas cartas, as quais sinalizam algumas das predileções que Alencar arrolaria em Como e por que sou romancista, surge uma história publicada em 1788, mas ainda muito popular no século xIx, Paulo e Virgínia, de Bernardin de Saint-Pierre, que provavelmente foi leitura do menino Alencar nos serões em família no volume da Impressão Régia do Rio de Janeiro de 1811:

[...] lembro-me que para nós filhos desta terra não há árvore talvez mais prosaica do que a bananeira, que cresce ordinariamente entre montões de cisco, em qualquer quintal de cidade, e cujo fruto nos desperta a ideia grotesca de um homem apalermado ou de um alarve.

Pois bem, meu amigo, recorde-se de Paulo e Virgínia, e daquelas bananeiras que cresciam perto da choupana, abrindo seus leques verdes às auras da tarde, veja como Bernardim (sic) de Saint-Pierre soube dar poesia a uma coisa que nós consideramos como tão vulgar. ${ }^{10}$

Tudo indica que Alencar se refere - oferecendo até mais poesia do que o original - à passagem: “[...] ao longo do rio e em torno das choupanas, pôs bananeiras que por

Ver CANDIDO, Antonio. Formação da literatura brasileira, op. cit., p. 321-4, e Valéria de Marco. O império da cortesã: Lucíola, um perfil de Alencar, op. cit., p. 13-23. poema. Maria Eunice Moreira e Luis Bueno (Orgs.). Curitiba: Editora da UFPR, 2007, p. xlvii.

10 Idem, p. xxxix. 
todo o ano dão cachos compridos e oferecem uma bela sombra". ${ }^{11}$ Esse é o lar dos dois jovens que crescem como irmãos na Ilha de França, no Oceano Índico, em contato direto com uma natureza prodigiosa, permanecendo puros e íntegros. Saint-Pierre, na esteira de seu amigo Rousseau, se opõe, em sua terna história, à sociedade que perverteria o homem:

Vós, europeus, cujo espírito se enche desde a infância de tantas preocupações contrárias à felicidade, não podeis conceber que a natureza possa dar tantas luzes e prazeres. Vossa alma, circunscrita numa pequena esfera de conhecimentos humanos, chega ao termo de suas fruições artificiais; mas a natureza e o coração são inesgotáveis. Paulo e Virgínia não tinham nem relógios, nem calendários, nem livros de cronologia, de história e de filosofia. Os períodos da sua vida se regulavam sobre os da natureza. [...]

[...] Assim cresciam ambos esses filhos da natureza. Nenhum cuidado tinha enrugado seu rosto; nenhuma intemperança tinha corrompido seu sangue; nenhuma paixão desgraçada tinha depravado seu coração; o amor, a inocência e a piedade desenvolviam cada dia a beleza das suas almas em graças inefáveis, nas suas feições, nas suas posturas e nos seus movimentos. Na madrugada da vida tinham toda a fresquidão dela; tais no Jardim do Éden pareceram nossos primeiros pais, quando saindo das mãos de Deus, se viram, se chegaram um do outro, conversaram ao princípio como irmão e irmã. Virgínia, doce, modesta, confiante como Eva; e Paulo, semelhante a Adão, tendo o talhe de um homem, com a simplicidade de um menino. ${ }^{12}$

A prosa poética de Saint-Pierre não teria sido apenas mais um contraexemplo para a epopeia de Gonçalves de Magalhães. Como veremos mais adiante, a fonte de Paulo e Virgínia que passava discreta pela aluvião da batalha a favor ou contra A confederação dos Tamoios pode ter ressoado com mais força até transbordar em uma enchente. Por enquanto, registremos que a estreia do Alencar romancista se deu no final desse 1856 com Cinco minutos, publicado no rodapé do Diário do Rio de Janeiro. A partir das peripécias romanescas dessa curta história, que está longe de anunciar um romancista de fôlego, se entrevê o narrador, "moço elegante" da rua do Ouvidor, em mais de um momento ansiar por um quadro idílico à maneira de Paulo e Virgínia:

Quatro novelas em tempos de d. João. Lúcia Maria Bastos Pereira das Neves e Luiz Carlos Villalta (Orgs.). Rio de Janeiro: Casa da Palavra, 2008, p. 73.

12 Idem, p. 93-4. 
Fazia-me lembrar da vida campestre, dessa existência doce e tranquila que se passa longe das cidades, quase no seio da natureza.

Pensava como seria feliz vivendo com ela em algum canto isolado, onde pudéssemos abrigar o nosso amor em um leito de flores e de relva.

Fazia na imaginação um idílio encantador, e sentia-me tão feliz que não trocaria a minha cabana pelo mais rico palácio da terra. ${ }^{13}$

Sob essa perspectiva, resumiríamos o primeiro romance de Alencar como a história de um rapaz da Corte que apenas encontra a felicidade ao lado de sua amada no retiro da natureza que lembraria um paraíso perdido, o qual, no fim da carta do narrador à prima Carlota, sabemos que se localiza em Minas Gerais. O começo do idílio é o final do romance. Mas Alencar deseja ir mais longe, inclusive recuando no tempo, para garantir esse idílio, e mais uma vez temos um epílogo, só que agora mais distendido, até porque poderia servir de roteiro para o romancista que se confirmava em $O$ guarani. O Epílogo ocupa muito mais páginas que os demais capítulos de O guarani, os quais, por sua concisão, nos remetem a sua origem no espaço dedicado ao folhetim que circulou de janeiro a abril de 1857 no Diário do Rio de Janeiro. Talvez as cinco partes do Epílogo discriminadas por espaços maiores correspondam a cinco tiradas do folhetim, e na passagem para o livro no mesmo ano o autor resolveu juntá-las. Mas o que importa notar nesse Epílogo é o refluxo da vertiginosa ação do romance em torno dos dois protagonistas, Peri e Ceci, que pela primeira vez efetivamente se deparam, "essas duas criaturas abandonadas no meio do deserto, sós em face da natureza". ${ }^{14} \mathrm{O}$ portentoso fim que parecia estar figurado na destruição do solar de d. Antonio de Mariz ainda não era suficiente. Alencar prolonga um pouco mais a história, como se recobrasse o fôlego e suspendesse os recursos folhetinescos que haviam aguçado a curiosidade do leitor. Pouco depois das cartas sobre A confederação dos Tamoios e antes dos vários prefácios, pós-escritos e autobiografia, um Epílogo talvez esboce um projeto de romance.

Os leitores e a crítica geralmente se lembram da última parte do Epílogo, a inundação do Paraíba, durante a qual os dois se abrigam no alto de uma palmeira, e, num último

ALENCAR, José de. Cinco minutos. A viuvinha. A pata da gazela. Encarnação. 3. ed. Rio de Janeiro: José Olympio, 1955, p. 42.

14 Idem. O guarani, tomo II. Rio de Janeiro: José Olympio, 1951, p. 513.

Teresa revista de Literatura Brasileira [12|13]; São Paulo, p. 525-542, 2013 • 531 
lance de heroísmo, Peri arranca o vegetal do solo para flutuarem sobre as águas: "A palmeira arrastada pela torrente impetuosa fugia...// E sumiu-se no horizonte...". As reticências finais por um lado embalaram os devaneios de gerações de leitores, e, por outro, convidaram os intérpretes a sugerir o propósito do autor de oferecer ao romance histórico uma dimensão mítica para a origem da nação brasileira, a partir da possível união do índio e da mulher branca. Nessa direção, são lapidares as observações de Alfredo Bosi no ensaio "Um mito sacrificial: o indianismo de Alencar": "Cancelam-se aqui os limites históricos, desfazem-se os contornos da vida em sociedade; e a narração volta-se para as fontes arcanas do romance histórico: a lenda". ${ }^{15}$ A seguir, Bosi se aproxima mais do referencial literário que conduz o final de O guarani, diferenciando-o do restante do romance: "Na solidão da mata, na canoa que resvala sobre a água lisa do Paraíba, a narrativa se arma sinuosamente para as formas do idílio". ${ }^{16}$ Acreditamos que trazer à tona a presença de Paulo e Virgína de Bernardin de Saint-Pierre no Epílogo de O guarani de Alencar seja fundamental para a análise mais detida do momento anterior à catástrofe final. Araripe Júnior em seu opúsculo dedicado ao conterrâneo cearense em 1882 teria sido o primeiro a sinalizar uma aproximação entre os dois textos: "No epílogo, parece que se concentraram todos os beijos dessa musa sorridente. É, talvez, o único idílio, em língua portuguesa, que rivalize com a bucólica austral de Saint-Pierre [...]". ${ }^{17}$ Inclusive o sentido em grego da palavra idílio como "forma pequena", que por extensão remete a um episódio em um poema que descreva a vida no campo, pode ajudar a entender a singularidade d'O Epílogo ante o restante do romance, que por muito tempo intrigou os intérpretes, começando por Araripe Júnior, que, em nota a essa passagem citada, chegou a recorrer a um episódio pessoal: “O que é para admirar é que José de Alencar dera por acabado o romance com a catástrofe em que desabou a casa de d. Antonio de Mariz. Mas, a pedido de suas irmãs, que liam a obra com o máximo interesse, permitiu escrever esse epílogo [...]". ${ }^{18}$

BOSI, Alfredo. Dialética da colonização. São Paulo: Companhia das Letras, 1992, p. 192.

Idem, p. 192.

17 ARARIPE JÚNIOR, Tristão de Alencar. Araripe Júnior: teoria, crítica e história literária. Edição de Alfredo Bosi. Rio de Janeiro: Livros Técnicos e Científicos; São Paulo: Edusp, 1978, p. 61-2.

18 Idem, p. 62. Maria Cecília Boechaet, considerando essa nota de Araripe como "folclore literário", oferece uma interpretação da singularidade do Epílogo de O guarani. (Paraísos artificiais: o romantismo de José de Alencar e sua recepção crítica. Belo Horizonte: Editora da UFMG/Programa de Pós-Graduação em Letras, Estudos Literários - FALE/UFMG, 2003, p. 129-48).

532 CARVALHO, Ricardo Souza de. O Epílogo de O guarani e os caminhos do romance 
Além da situação geral de Paulo e Virgínia na ilha, novos Adão e Eva tropicais, o episódio em que se encontram desorientados no meio da floresta e o desvelo do rapaz para com a moça talvez tenham ecoado na missão de Peri em salvar Cecília:

[...] Desceram, pois, o outeiro do rio Negro, do lado do norte, e chegaram, depois de ter andado uma hora, à margem de um largo rio que lhes impedia a passagem. [...] O rio, sobre cuja borda se achavam, corre em borbotões, sobre um leito de rochas. $\mathrm{O}$ estrondo de suas águas assustou Virgínia: nelas não ousou pôr os pés para passá-las a vau. Paulo carregou então com Virgínia aos ombros e passou carregado deste modo sobre as rochas escorregadiças do rio, apesar do tumulto de suas águas. [...] Chegado que foi Paulo à margem, quis continuar seu caminho carregando com sua irmã, e se lisonjeava de subir assim a montanha das Três Mamas, que via diante de si a meia légua dali; mas logo lhe faltaram as forças e foi obrigado a pô-la em terra e a descansar ao lado dela. Virgínia disse então: "Meu irmão, o dia declina; tu tens ainda forças, e as minhas me faltam; deixa-me aqui e volta só à nossa casa para aquietar nossas mães”. “Oh, não!”, disse Paulo, "eu não te deixarei. Se a noite nos apanhar nesta selva, eu acenderei lume, derribarei palmeiras, tu comerás o repolho delas e com suas folhas farei uma ajupá para abrigar-te”. ${ }^{19}$

O que pode ser mais uma atualização do tema imemorial do herói a proteger a frágil dama dos perigos e sobressaltos, em outros casos, fundamenta um diálogo mais direto entre Paulo e Virgínia e o Epílogo de O guarani. Em primeiro lugar, ao lado dos heróis, as delicadas Virgínia e Cecília descobrem novos sentimentos que as perturbam, e, por consequência, o mundo harmonioso em que viviam. Aqueles que encaravam apenas como irmãos começam a ser percebidos como homens. Virgínia "à vista de Paulo, ela ia para ele brincando; e depois, de repente, ao chegar-se a ele, um embaraço repentino a fazia parar, uma vermelhidão corava suas faces pálidas, seus olhos não ousavam já fitar-se nos seus"; quando ele a abraçava "se sentia perturbada pelas carícias de seu irmão". ${ }^{20}$ Ao se encerrar a primeira parte do Epílogo, Cecília "sentiu pela primeira vez na sua vida que o coração de Peri palpitava sobre o seu seio"; e quando "os seus olhos encontravam os de Peri, os longos cílios desciam ocultando um momento o seu olhar doce e triste". ${ }^{21}$ 
Nas três partes seguintes, antes da inundação, o narrador se detém em Cecília, tentando adentrar em seu pensamento ao ensaiar um discurso indireto livre. Enquanto Peri prossegue inabalável no caráter quase mecânico de suas ações desde o início do romance, Cecília, embora rapidamente, se transforma da ingênua menina alvo dos desejos de alguns personagens na mulher que se questiona, se mostra imperiosa, decidida, antecipando o gosto de Alencar em explorar os incomuns "perfis de mulher". Pelo menos nesse Epílogo, Cecília é a irmã mais velha de Lúcia e de Aurélia Camargo.

Na segunda parte do Epílogo, ao fazer um retrospecto da sua vida, Cecília constata que algo que ela ainda não sabia definir mudou em sua vida a partir da destruição de seu lar e da perda de seus pais:

Cecília repassava na memória toda a sua vida inocente e tranquila, cujo fio dourado tinha-se rompido de uma maneira tão cruel; mas era sobretudo o último ano dessa existência, desde o dia do aparecimento imprevisto de Peri, que se desenhava na sua imaginação.

Por que interrogava ela assim os dias que tinha vivido no remanso da felicidade? Por que o seu espírito voltava ao passado, e procurava ligar todos esses fatos a que na descuidosa ingenuidade dos primeiros anos dera tão pouco apreço?

Ela mesma não saberia explicar as emoções que sentia; sua alma inocente e ignorante tinha-se iluminado com uma súbita revelação; novos horizontes se abriam aos sonhos castos do seu pensamento.

Volvendo ao passado admirava-se de sua existência, como os olhos se deslumbram com a claridade depois de um sono profundo; não se reconhecia na imagem do que fora outrora, na menina isenta e travessa.

Toda a sua vida estava mudada; a desgraça tinha operado essa revolução repentina, e um outro sentimento ainda confuso ia talvez completar a transformação misteriosa da mulher. $^{22}$ 
Mais adiante, em uma atitude mais ousada, Cecília vela o sono de Peri, e os pressentimentos iniciais se tornam mais claros:

Contemplando essa cabeça adormecida, a menina admirou-se da beleza inculta dos traços, da correção das linhas do perfil altivo, da expressão de força e inteligência que animava aquele busto selvagem, moldado pela natureza.

Como é que até então ela não tinha percebido naquele aspecto senão um rosto amigo? Como seus olhos tinham passado sem ver sobre essas feições talhadas com tanta energia? É que a revelação física que acabava de iluminar o seu olhar, não era senão o resultado dessa outra revelação moral que esclarecera o seu espírito; dantes via com os olhos do corpo, agora via com os olhos da alma.

Peri, que durante um ano não fora para ela senão um amigo dedicado, aparecia-lhe de repente como um herói; no seio de sua família estimava-o, no meio dessa solidão admirava-0. ${ }^{23}$

A partir dessa mudança de percepção de Cecília na passagem do mundo civilizado, representado pelo solar de $\mathrm{d}$. Antonio, para a natureza, o narrador segue em suas considerações; não se trata mais do pensamento da moça, mas do Alencar político e escritor do século XIX:

Como os quadros dos grandes pintores que precisam de luz, de um fundo brilhante, $\mathrm{e}$ de uma moldura simples, para mostrarem a perfeição de seu colorido e a pureza de suas linhas, o selvagem precisava do deserto para revelar-se em todo o esplendor.

No meio de homens civilizados, era um índio ignorante, nascido de uma raça bárbara, a quem a civilização repelia e marcava o lugar de cativo. Embora para Cecília e d. Antonio fosse um amigo, era apenas um escravo.

Aqui, porém, todas as distinções desapareciam; o filho das matas, voltando ao seio de sua mãe, recobrava a liberdade; era o rei do deserto, o senhor das florestas, dominando pelo direito da força e da coragem. ${ }^{24}$

23 Idem, p. 516.

24 Idem, p. 516-7. 
Esse trecho coloca em suspenso a afirmativa de que a História foi abolida do Epílogo. Aqui não se fala mais do Peri personagem idealizado, mas do que o autor acredita ser a posição do índio na constituição da nação brasileira: ele precisa da natureza, do seu meio natural, para ser visto, valorizado; na sociedade apenas poderia ser um escravo. Mas todos sabiam que isso não fora possível. Dez anos depois, segundo Alencar em seu livro Ao imperador: novas cartas de Erasmo, a impossibilidade da escravidão do indígena teria forçado o tráfico do escravo africano:

Se a raça americana suportasse a escravidão, o tráfico não passara de acidente, e efêmero. Mas, por uma lei misteriosa, essa grande família humana estava fatalmente condenada a desaparecer da face da terra, e não havia para encher esse vácuo senão a raça africana. Ao continente selvagem, o homem selvagem. Se este veio embrutecido pela barbaria, em compensação trouxe a energia para lutar com uma natureza gigante..$^{25}$

Então, retornemos ao "continente selvagem", à "natureza gigante", do Epílogo de $O$ guarani. Peri naturalmente se apresenta como escravo de Cecília - reminiscência do período em que ficou entre os Mariz - mas logo a donzela corrige para irmão, já que o nome de amado também não é permitido. Novamente, saímos dos terrenos da História e ingressamos no idílio.

Passando à terceira parte do Epílogo, ao deixar por um instante Cecília sozinha, o narrador se permite esclarecer o que ela sentia por Peri:

Cecília amava; a gentil e inocente menina procurava iludir-se a si mesma, atribuindo o sentimento que enchia sua alma a uma afeição fraternal, e ocultando, sob o doce nome de irmão, um outro mais doce que titilava nos seus lábios, mas que seus lábios não ousavam pronunciar.

Mesmo só, de vez em quando um pensamento que passava no seu espírito, incendia-lhe as faces de rubor, fazia palpitar-lhe o seio e pender molemente a cabeça, como a haste da planta delicada quando o calor do sol fecunda a florescência.

Em que pensava ela, com os olhos fitos no íris, que o seu hálito bafejava, com as pálpebras meio cerradas e o corpo reclinado sobre os joelhos?

25 ALENCAR, José de. Cartas a favor da escravidão. Organização de Tamis Parron. São Paulo: Hedra, 2008, p. 69. 
Pensava no passado que não voltaria; no presente que devia escoar-se rapidamente; e no futuro que aparecia vago, incerto e confuso. ${ }^{26}$

Se avançarmos um pouco mais na proximidade entre os pensamentos de Cecília e os do narrador, essa última frase também caberia a um Alencar que iniciava a concepção do seu romance e da história brasileira, ainda não tão nítida como no prefácio "Bênção paterna”. De um lado, um passado "que não voltaria mais", propício às lendas e aos romances históricos; de outro, um presente "que devia escoar-se rapidamente" e um futuro "que aparecia vago, incerto e confuso" nos romances contemporâneos do campo e da cidade.

Apesar do idílio, tanto a ilha de Paulo e Virgínia, quanto a "natureza gigante" d’O Epílogo não são mundos autônomos, pois estão submetidos às suas respectivas metrópoles, França e Portugal. Justamente nos momentos mais tensos - pelo menos para a leitura que aqui pretendemos - de ambas as narrativas, esses espaços da civilização e do poder ameaçam romper a harmonia do idílio: de um lado, Virgínia vê-se forçada a ir para Paris sob os cuidados de uma tia de sua mãe, a fim de receber "uma boa educação, um partido na Corte e a doação de todos os seus bens"; ${ }^{27}$ de outro, Cecília deve chegar a salvo ao Rio de Janeiro, cidade que "tinha-se fundado havia menos de meio século, e a civilização não tivera tempo de penetrar o interior" como consta no primeiro capítulo do romance. ${ }^{28}$

Paulo não se conforma com a partida de Virgínia, porém toma consciência de que uma distância maior os separa, como lhe conta sua mãe: "Por que, filho meu, te alimentas com falsas esperanças, que tornam ainda mais amargas as privações? É tempo que eu te descubra o segredo da tua vida e da minha. A jovem senhora de La Tour pertence por parte de sua mãe a uma parenta rica e de grande nobreza. Quanto a ti, tu não és senão o filho de uma pobre camponesa, e o pior é que tu és bastardo". 29 Mesmo assim, ele faz um último e vão apelo a Virgínia: “[...] em França, onde tu vais buscar fortuna e grandeza, eu te servirei como teu escravo". ${ }^{\circ}$ Virgínia não se deixaria encantar por essa fortuna e grandeza, por uma sociedade requintada, percebendo que seu verdadeiro lar está na ilha com sua família e com Paulo. Passados três anos

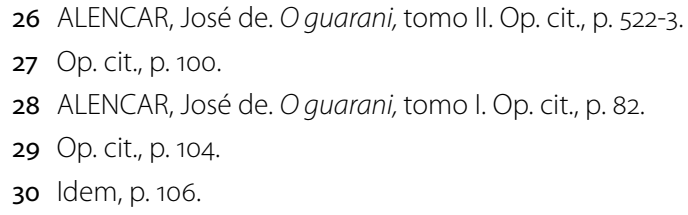


e meio na França, deserdada pela tia, a moça retorna, mas morre em um naufrágio. Um Paulo desolado falece logo depois. O fim trágico dos protagonistas ratifica a oposição que a história de Bernardin de Saint-Pierre estabelece entre as virtudes da natureza diante da corrupção da Europa dita civilizada.

Embora Cecília não queira abandonar Peri, este lhe lembra o que o narrador já mencionara a respeito da diferente posição ocupada por ele na natureza e na cidade: “Tu és boa; mas todas as que têm a tua cor não têm o teu coração. Lá o selvagem seria um escravo dos escravos; e quem nasceu o primeiro pode ser teu escravo; mas é senhor dos campos, e manda aos mais fortes". ${ }^{31}$ Cecília concorda, fazendo eco ao juízo do narrador e à fala de Peri, selando o não lugar do índio na cidade do homem branco: "Qual não seria pois a consequência dessa outra transição, muito mais brusca? Numa cidade, no meio da civilização, o que seria um selvagem, senão um cativo, tratado por todos com desprezo?".32

Chegamos à quarta parte do Epílogo de $O$ guarani, e é nesse ponto que as similaridades com Paulo e Virgínia tomam rumos diferentes. Mais uma vez, Araripe Júnior lançara um sugestivo contraste, sem desenvolvê-lo, ao considerar Cecília "mais petulante que a Virginia de Saint-Pierre, pudica simplesmente, como Eva, antes do pecado".33 A personagem brasileira, em ato mais corajoso e arriscado do que a palmeira arrancada por Peri, resolve ficar ao lado do índio no "meio das florestas". Como ápice dos instantes anteriores que focalizaram a reflexão da moça, o narrador explica as razões dela que aqui entendemos como suas próprias justificativas em relação ao seu romance:

Não foi sem algum esforço que ela conseguiu dominar os primeiros temores que a assaltaram, quando encarou em face essa existência longe da sociedade, na solidão, no isolamento.

Mas qual era o laço que a prendia ao mundo civilizado? Não era ela quase uma filha desses campos, criada com o seu ar puro e livre, com as suas águas cristalinas?

A cidade lhe aparecia apenas como uma recordação da primeira infância, como um sonho do berço; deixara o Rio de Janeiro aos cinco anos, e nunca mais ali voltara. 
O campo, esse tinha para ela outras recordações ainda vivas e palpitantes; a flor da sua mocidade tinha sido bafejada por essas auras; o botão desatara aos raios desse sol esplêndido.

\section{$[\ldots]$}

Ela pertencia, pois, mais ao deserto do que à cidade; era mais uma virgem brasileira do que uma menina cortesã; seus hábitos e seus gostos prendiam-se mais às pompas da natureza do que às festas e às galas da arte e da civilização.

Decidiu ficar. ${ }^{34}$

Não importa tanto se Peri chegaria a cumprir a promessa feita a d. Antonio de Mariz de levar Cecília, se os dois sucumbiriam na inundação (mortos como Paulo e Virgínia), ou se viveriam juntos na floresta. A decisão de Cecília em ficar seria o centro de força do Epílogo de O guarani, mais metafórico do que episódico. Passemos à definição de literatura nacional no prefácio "Bênção paterna", "que outra cousa é senão a alma da pátria, que transmigrou para este solo virgem com uma raça ilustre, que aqui impregnou-se da seiva americana desta terra que lhe serviu de regaço". ${ }^{35}$ Essa caracterização já teria sido insinuada no processo de transformação de Cecília: essa filha de Portugal, que se parece com o pai - "lembrava o caráter de d. Antonio de Mariz", "ia cumprir com a mesma força de vontade e coragem que herdara de seu pai" - se reconhece, antes de tudo, como "filha desta terra; também me criei no seio desta natureza. Amo este belo país!...” ${ }^{36}$ Mas a definição de literatura brasileira em "Bênção paterna" não está completa, faltando ainda o trecho: "e cada dia se enriquece ao contato de outros povos e ao influxo da civilização". Como vimos no começo, essa importação estrangeira estaria na base dos romances urbanos de Alencar. E o dilema de Cecília no Epílogo, entre ir para a cidade ou ficar na natureza, é iluminador na medida em que indica as intuições de um Alencar que somente mais tarde se tornariam mais nítidas. A cidade para onde a moça deveria ser levada, mais do que o acanhado centro urbano que era o Rio de Janeiro no século xviI, apresenta dimensões vagas e pode ser a Corte do século XIX retratada nas peças e romances

\footnotetext{
34 Idem, p. 529-30.

35 ALENCAR, José de. Bênção paterna. In: Sonhos d'ouro, op. cit., p. 34

36 Idem, p. 531.
} 
alencarianos. Cecília não se lembra mais dessa cidade, e realmente não precisa, pois Alencar sabe muito bem de qual se trata. $\mathrm{O}$ narrador apenas insinua o possível destino de Cecília na cidade ao contrapor a "virgem brasileira" à "menina cortesã". Os costumes estrangeiros - entendam-se aqueles que não fazem parte da origem lusitana adaptada às condições americanas - corromperiam a virgindade da nação. O modelo do confronto entre a Europa corrupta e a natureza redentora de Paulo e Virgínia ganha contornos mais específicos no Epílogo de O guarani, ao englobar uma concepção de romance e de história para o Brasil.

Apesar da resolução de Cecília em ficar, a hesitação voltaria constantemente na obra de Alencar. Tanto que a "virgem brasileira" vai até a cidade experimentar ser a "menina cortesã". Cinco anos depois de O guarani, Alencar voltaria ao romance de forma contundente com Lucíola, ao abordar a degradação feminina no espaço urbano por meio da prostituição. Tendo escrito nesse intervalo o pequeno romance A viuvinha e se dedicado ao teatro, estamos longe de vislumbrar o painel proposto em "Bênção paterna”. Mas o projeto já havia sido esboçado no Epílogo de O guarani e se desdobraria em Lucíola. E mais uma vez a sombra das bananeiras de Paulo e Virgínia comparece.

O bacharel Paulo desconcerta-se diante das "rápidas transições" de Lúcia, "que transfigurava de repente a cortesã depravada na menina ingênua, ou na amante apaixonada!"” ${ }^{37}$ Aos poucos, o enigma começa a ser desfeito quando ela se dispõe a lhe contar "as impressões de sua infância passada no campo entre as árvores e à borda do mar; seu espírito adejava com prazer sobre essas reminiscências embalsamadas com os agrestes perfumes da mata, e por vezes a poesia da natureza fluía no seu ingênuo entusiasmo". ${ }^{8}$ Até que essa outra face de Lúcia se encontra com um romance que a atinge profundamente:

O livro que ela trouxe era esse gracioso conto de Bernardin de Saint-Pierre, que todos lemos uma vez aos quinze anos, quando ainda não o sabemos compreender; e outra aos trinta, quando já não o podemos sentir. O que seduzira Lúcia foi o nome de Paulo que ela ao entregar-me o volume mostrara sorrindo. Quando eu lia a descrição das duas cabanas e a infância dos amantes, Lúcia deixou pender a cabeça sobre o seio, cruzou as mãos nos joelhos dobrando o talhe [...]

37 ALENCAR, José de. Lucíola. Diva. 3. ed. Rio de Janeiro: José Olympio, 1955, p. 79-80.

38 Idem, p. 132. 
De repente a voz desatou num suspiro:

- Ah! meu tempo de menina!

Voltei-me para ela; as lágrimas caíam-lhe em bagas; quis atraí-la, fugiu, arrebatando-me o livro das mãos. ${ }^{39}$

Paulo e Virgínia, referência literária nas cartas sobre A confederação dos Tamoios e no Epílogo de O guarani, se torna em Lucíola um espelho em que a personagem se vê. Lúcia emociona-se não apenas ao reconhecer sua infância campestre no idílio de Saint-Pierre, mas talvez porque se desse conta da impossibilidade de vivê-lo novamente. $\mathrm{O}$ episódio parece indicar que a leitura foi interrompida e Lúcia não quis saber o destino dos jovens. Mas sua própria trajetória no romance acompanha o mundo que se desagrega em Paulo e Virgínia: mesmo abandonando a prostituição e a agitação da Corte, ao lado de seu Paulo, ela sucumbe. Na cidade, assim como Peri seria escravo, à menina pobre caberia o papel de prostituta.

Ante o caso da "desistência" de Lúcia, reforça-se a firme resolução de Cecília, essa sim legítima representante da nação brasileira, que subverte o modelo literário de Paulo e Virgínia do qual foi aproximada. Não devemos esquecer, porém, que ela chegou a hesitar entre ir para a cidade ou permanecer na natureza, o que encaminhou as oscilações de Alencar em tempos e espaços diferentes em seus romances. Se a exaltação do estado natural e a aversão pelo progresso bebido nos avatares do romantismo puderam conformar o projeto alencariano, a hipótese de Candido de uma expansão espaçotemporal do romance para escapar das limitações de uma vida urbana que copia em escala menor a Europa continua a instigar. Basta lembrar que na mesma Lucíola, logo no primeiro capítulo, Paulo, recém-chegado da província, em meio à festa da Glória admira-se com a variedade de pessoas que desfilam a sua frente:

Todas as raças, desde o caucasiano sem mescla até o africano puro; todas as posições, desde as ilustrações da política, da fortuna ou do talento, até o proletário humilde e desconhecido; todas as profissões, desde o banqueiro até o mendigo; finalmente, todos os tipos grotescos da sociedade brasileira, desde a arrogante nulidade até a vil lisonja, desfilaram em face de mim, roçando a seda e a casimira pela baeta e pelo algodão, mis- 
turando os perfumes delicados às impuras exalações, o fumo aromático do havana às acres baforadas do cigarro de palha.

É uma festa filosófica essa festa da Glória! Aprendi mais naquela meia hora de observação do que nos cinco anos que acabava de esperdiçar em Olinda com uma prodigalidade verdadeiramente brasileira. ${ }^{40}$

Contudo, essa promessa de romances que não se cumpriram foi o máximo a que Alencar se permitiu na cidade. Decidiu ficar no seu Brasil como Cecília.

Ricardo Souza de Carvalho é professor de Literatura Brasileira na Universidade de São Paulo, autor de A Espanha de João Cabral e Murilo Mendes (Editora 34, 2011), bem como de artigos sobre a literatura brasileira de fins do século xIx e a poesia brasileira do século xx. 